\title{
Immunolocalization of Kisspeptin Associated with Amyloid- $\beta$ Deposits in the Pons of an Alzheimer's Disease Patient
}

\author{
Amrutha Chilumuri, ${ }^{1}$ Maria Ashioti, ${ }^{1}$ \\ Amanda N. Nercessian, ${ }^{2}$ and Nathaniel G. N. Milton ${ }^{1,2}$ \\ ${ }^{1}$ Department of Human and Health Sciences, School of Life Sciences, University of Westminster, \\ 115 New Cavendish Street, London W1W 6UW, UK \\ ${ }^{2}$ Health Sciences Research Centre, University of Roehampton, Holybourne Avenue, London SW15 4JD, UK \\ Correspondence should be addressed to Nathaniel G. N. Milton; n.milton@westminster.ac.uk
}

Received 3 February 2013; Revised 23 April 2013; Accepted 24 April 2013

Academic Editor: Gal Bitan

Copyright (C) 2013 Amrutha Chilumuri et al. This is an open access article distributed under the Creative Commons Attribution License, which permits unrestricted use, distribution, and reproduction in any medium, provided the original work is properly cited.

\begin{abstract}
The pons region of the Alzheimer's disease (AD) brain is one of the last to show amyloid- $\beta(\mathrm{A} \beta)$ deposits and has been suggested to contain neuroprotective compounds. Kisspeptin (KP) is a hormone that activates the hypothalamic-pituitary-gonadal axis and has been suggested to be neuroprotective against $\mathrm{A} \beta$ toxicity. The localization of $\mathrm{KP}$, plus the established endogenous neuroprotective compounds corticotropin releasing hormone $(\mathrm{CRH})$ and catalase, in tissue sections from the pons region of a male AD subject has been determined in relation to $\mathrm{A} \beta$ deposits. Results showed $\mathrm{A} \beta$ deposits also stained with $\mathrm{KP}, \mathrm{CRH}$, and catalase antibodies. At high magnification the staining of deposits was either KP or catalase positive, and there was only a limited area of the deposits with $\mathrm{KP}$-catalase colocalization. The $\mathrm{CRH}$ does not bind $\mathrm{A} \beta$, whilst both $\mathrm{KP}$ and catalase can bind $\mathrm{A} \beta$, suggesting that colocalization in $\mathrm{A} \beta$ deposits is not restricted to compounds that directly bind $\mathrm{A} \beta$. The neuroprotective actions of $\mathrm{KP}, \mathrm{CRH}$, and catalase were confirmed in vitro, and fibrillar A $\beta$ preparations were shown to stimulate the release of KP in vitro. In conclusion, neuroprotective $\mathrm{KP}, \mathrm{CRH}$, and catalase all colocalize with $\mathrm{A} \beta$ plaque-like deposits in the pons region from a male $\mathrm{AD}$ subject.
\end{abstract}

\section{Introduction}

The deposition of the amyloid- $\beta(\mathrm{A} \beta)$ peptide within plaques in the Alzheimer's disease (AD) brain is a central feature of the disease pathology $[1,2]$. A sequential pattern of $A \beta$ deposition within different regions of the brain has been suggested as $\mathrm{AD}$ progresses [3-6]. The staging of $\mathrm{A} \beta$ deposition by Thal et al. (2002) [3] identified the cerebellum plus brainstem nuclei including the pons as the last to show $\mathrm{A} \beta$ deposits. In transgenic mice overexpressing the human amyloid precursor protein (APP) the $\mathrm{A} \beta$ deposition showed a similar sequential pattern, with the cerebellum and pons again the last to show $\mathrm{A} \beta$ deposits [7]. The apparent resistance of the cerebellum and pons to neurodegenerative changes suggests that endogenous neuroprotective processes may play a role in these tissues.

A range of endogenous compounds have been suggested to have neuroprotective properties against $\mathrm{A} \beta$ in $\mathrm{AD}$ models
[8-16]. In a recent study kisspeptin (KP) peptides were suggested to have neuroprotective properties against $\mathrm{A} \beta$ plus related amyloid proteins [17]. The KP peptide is a reproductive hormone [18], and the female hypothalamic levels of KP show elevations after menopause that are not seen in males [19]. Female AD onset is typically postmenopausal, and there is significantly less neurodegeneration in the hypothalamus in women compared to men [20]. The release of KP from human neuronal cells has been shown to be stimulated by $\mathrm{A} \beta$ [17] suggesting that in regions that express the KiSS-1 gene, which encodes for the KP peptides, there may be changes in $\mathrm{KP}$ levels in $\mathrm{AD}$ due to the elevations of $\mathrm{A} \beta$.

The KP peptide was identified as having similarity to the catalase region that binds $\mathrm{A} \beta$ [21], and $\mathrm{KP}$ binds $\mathrm{A} \beta$ itself [17]. Catalase has been shown to bind directly to $\mathrm{A} \beta$ fibrils [22] and has been found by immunohistochemistry in amyloid plaques in $\mathrm{AD}$ brains [23]. The catalase enzyme has been shown to have neuroprotective properties as an antioxidant 
enzyme $[24,25]$, as an $\mathrm{A} \beta$ binding protein $[26,27]$ and when targeted to the mitochondria as a modifier of $\mathrm{A} \beta$ secretion [12]. The CRH peptide has well-established neuroprotective properties and prevents $\mathrm{A} \beta$ toxicity $[10,28-33]$. The mechanism for $\mathrm{CRH}$ neuroprotection, unlike KP neuroprotection, is receptor mediated [30-32], and the peptide does not bind $\mathrm{A} \beta$, unlike catalase and $\mathrm{KP}[17,26]$. In $\mathrm{AD}$ the $\mathrm{CRH}$ peptide has been found to be associated with thioflavin S-positive deposits [34], and the levels of $\mathrm{CRH}$ are markedly reduced in some brain regions $[35,36]$.

The KP peptide [37, 38], CRH peptide [39], and catalase $[40,41]$ are all found in the pons, where neurodegenerative changes and $\mathrm{A} \beta$ deposition occur in the latter stages of the disease $[3,7]$. In this study the localization of immunoreactive (ir-) KP, $\mathrm{CRH}$, and catalase in relation to $\mathrm{A} \beta$ deposits has been determined in pons sections from a male $\mathrm{AD}$ patient. The neuroprotective effects of KP, CRH, and catalase plus ir-KP release from human SH-SY5Y neuroblastoma cells have also been studied.

\section{Materials and Methods}

2.1. Materials. Pons sections from a 72-year-old male with AD (Cat. no. ab4586; Lot no. B506287) and a 26-year-old normal male (Cat. no. ab4316; Lot no. A504234) and BAM-10 mouse anti-A $\beta$ antibody were obtained from Abcam PLC, Cambridge, UK. Rabbit anti-KP 45-54 antiserum, KP 1-54, KP 42-54, KP 45-54, KP 45-50, neuropeptide-FF (NPFF), $\mathrm{CRH}, \mathrm{A} \beta 1-46, \mathrm{~A} \beta$ 1-43, $\mathrm{A} \beta$ 1-42, $\mathrm{A} \beta 1-40, \mathrm{~A} \beta 1-38$, and A $\beta$ 17-40 were purchased from Bachem AG, Switzerland. Goat anti-mouse IgG Alexa Fluor 568 and goat anti-rabbit IgG Alexa Fluor 488 were purchased from Chemicon, UK. VECTASHIELD Mounting Media was purchased from Vector Laboratories Ltd., UK. The CAT-505 mouse anti-catalase antibody, alkaline phosphatase conjugated goat anti-rabbit IgG, alkaline phosphatase conjugated anti-mouse IgG, and all other chemicals were purchased from Sigma-Aldrich, UK.

2.2. A $\beta$ Fibril Formation. Batches of synthetic $\mathrm{A} \beta 1-46, \mathrm{~A} \beta 1-$ 43, $\mathrm{A} \beta$ 1-42, $\mathrm{A} \beta$ 1-40, $\mathrm{A} \beta$ 1-38, $\mathrm{A} \beta$ 17-40, or $\mathrm{A} \beta 25-35$ were dissolved in distilled water at a concentration of $1.0 \mathrm{mg} / \mathrm{mL}$ and incubated at $37^{\circ} \mathrm{C}$ for $24 \mathrm{~h}$, with constant oscillation. Following incubation, the formation of fibrils was confirmed by TEM or Congo red assay as previously described by Milton and Harris [22, 42, 43].

2.3. Antibody Characterization. NUNC MaxiSorp 96-well immunoplates were coated with $1 \mu \mathrm{g} / \mathrm{mL}$ of either KP peptides, NPFF peptides, $\mathrm{CRH}$ peptides, catalase, or $\mathrm{A} \beta$ peptides in $50 \mathrm{mM}$ carbonate buffer, $\mathrm{pH}$ 9.6, and unoccupied sites blocked with $0.2 \%(\mathrm{w} / \mathrm{v})$ marvel. Either the BAM-10 mouse anti-A $\beta$ antibody [44], rabbit anti-A $\beta$ 21-32 antiserum [45], rabbit anti-KP 45-54 antiserum [17], KCHMB001 mouse anti-CRH antibody [46-48], or CAT-505 mouse anti-catalase antibody [49] at a final concentration of $0.1 \mu \mathrm{g} / \mathrm{mL}$ in $50 \mathrm{mM}$ TRIS (containing 0.1\% BSA and $0.1 \%$ Triton X-100) was added $(100 \mu \mathrm{L} /$ well $)$ and incubated at $4^{\circ} \mathrm{C}$ for 16 hours. Some plates were coated with A $\beta$ 1-42 fibrils, prepared, and tested as described by Milton and Harris (2009) [22], and these plates were preincubated at $4^{\circ} \mathrm{C}$ for 24 hours with $\mathrm{KP} 45-54, \mathrm{NPFF}, \mathrm{CRH}$ or catalase prior to addition of antibodies. After washing to remove unbound material an alkaline phosphatase conjugated goat anti-rabbit or antimouse secondary antibody was added and incubated at $24^{\circ} \mathrm{C}$ for 2 hours. After washing to remove unbound material pnitrophenylphosphate substrate was added and absorbance at $405 \mathrm{~nm}$ determined.

2.4. Immunohistochemistry and Confocal Microscopy. Premounted and paraffin-embedded pons tissue sections from a normal or an AD patient at a thickness of $5 \mu \mathrm{M}$ were used. The tissue had been examined and diagnosed by a licensed pathologist and was ethically obtained. The sections were processed for immunostaining [50] and incubated overnight at $4^{\circ} \mathrm{C}$ with $1: 1000$ dilutions $(1 \mu \mathrm{g} / \mathrm{mL}$ final concentration) of BAM-10 mouse anti-A $\beta$ antibody [44], rabbit anti-A $\beta$ 21-32 antiserum [45], rabbit anti-KP 45-54 antiserum [17], KCHMB001 mouse anti-CRH antibody [46-48], and CAT505 mouse anti-catalase antibody [49] in phosphate buffered saline containing $0.01 \%$ Tween 20 (PBST). For some of the incubations with anti-KP 45-54 the antibody solutions were preincubated with NPFF $(10 \mu \mathrm{g} / \mathrm{mL})$ for $24 \mathrm{~h}$ to block binding to endogenous NPFF [51]. The sections were then washed for $3 \times 5$ min with PBST before the secondary antibodies were applied (goat anti-mouse IgG-Alexa Fluor 568 and goat antirabbit IgG-Alexa Fluor 488, 1:500) for 1 hour. The sections were then washed in PBST, and cover slips were mounted with VECTASHIELD Mounting Media.

Images were acquired by sequential scanning using a Leica TCS SP2 confocal system (Leica Microsystems, Milton Keynes, UK) with a $63 x$ ceramic dipping objective. A $488 \mathrm{~nm}$ laser was used for excitation of Alexa Fluor 488 labeled goat anti-rabbit IgG, while a $543 \mathrm{~nm}$ laser was used for Alexa Fluor 568 labeled goat anti-mouse IgG excitation [52].

2.5. Cell Cultures. Human SH-SY5Y neuroblastoma cells were routinely grown in a $5 \% \mathrm{CO}_{2}$ humidified incubator at $37^{\circ} \mathrm{C}$ in a 1:1 mixture of Dulbecco's modified Eagle's medium and HAM's F12 with Glutamax (Invitrogen) supplemented with $10 \%$ fetal calf serum (FCS), $1 \%$ nonessential amino acids, penicillin (100 units $/ \mathrm{mL})$, and streptomycin $(100 \mathrm{mg} / \mathrm{mL})$ [53]. Human neuroblastoma SH-SY5Y cells were cultured in 6-well or 96-well plates and differentiated with retinoic acid for 7 days prior to experimentation.

2.6. KP Release. $2.5 \times 10^{5}$ differentiated SH-SY5Y cells/well in 6 -well plates were incubated in $4 \mathrm{~mL}$ of medium containing a subtoxic dose (100 $\mathrm{nM})$ of either fibrillar $\mathrm{A} \beta 1-46, \mathrm{~A} \beta 1-43$, $\mathrm{A} \beta$ 1-42, $\mathrm{A} \beta$ 1-40, $\mathrm{A} \beta$ 1-38, $\mathrm{A} \beta$ 17-40, or $\mathrm{A} \beta 25-35$ for $4 \mathrm{~h}$. Control cells were cultured in medium alone. Media was harvested and KP extracted using a polyclonal anti-KP 45-54 antiserum and a protein-A agarose column. The immunoreactive $\mathrm{KP}$ was eluted from the column in $0.5 \mathrm{M}$ acetic acid and was further purified using a Sep-Pak $\mathrm{C}_{18}$ extraction step. The Sep-Pak $\mathrm{C}_{18}$ columns were prewetted with methanol and $0.5 \mathrm{M}$ acetic acid, acidified samples applied, and columns washed with $0.5 \mathrm{M}$ Acetic acid prior to elution of bound peptide with $70 \%$ acetonitrile. After drying under a stream 
of nitrogen, samples were resuspended in PBS containing $0.1 \%$ BSA plus $0.05 \%$ Tween 20 .

2.7. Determination of $i r-K P$. ELISA plates were coated with $1 \mu \mathrm{g} / \mathrm{mL}$ anti-KP $45-54$ antiserum in $50 \mathrm{mM}$ carbonate buffer, $\mathrm{pH}$ 9.6, and unoccupied sites blocked with 5\% (w/v) marvel. Samples or synthetic KP $45-54$ standards $(0-1000 \mathrm{pg} / \mathrm{mL})$ were applied in assay buffer (PBS containing $0.1 \%$ BSA plus $0.05 \%$ Tween 20 ) and incubated for $24 \mathrm{~h}$. After washing with assay buffer to remove unbound material, biotinyl-KP 45-50 $(10 \mathrm{ng} / \mathrm{mL})$ was added and incubated for $2 \mathrm{~h}$. After washing to remove unbound material, immunoreactive- (ir-) KPlike material was detected using a streptavidin-horseradish peroxidase conjugate and $3,3^{\prime}, 5,5^{\prime}$-tetramethylbenzidine substrate [17]. Sample levels were compared to KP 45-54 standards and ir-KP-like peptide levels expressed as a \% of control cell release.

2.8. Effect of KP, CRH, and Catalase on $A \beta$ Neurotoxicity. On the day of the experiment $5 \times 10^{3}$ differentiated $\mathrm{SH}$ SY5Y cells/well in 96-well plates were pretreated with either media alone (control) or anti-KP 45-54 antibody $(10 \mu \mathrm{g} / \mathrm{mL})$ to block endogenous KP, KCHMB001 anti-CRH antibody $(10 \mu \mathrm{g} / \mathrm{mL})$ to block endogenous $\mathrm{CRH}$, or 3-aminotriazole (3AT: $50 \mu \mathrm{M}$ ) to inhibit endogenous catalase [24, 53] for a $4 \mathrm{~h}$ period. The $\mathrm{A} \beta 1-42(10 \mu \mathrm{M})$ was then added to induce toxicity, and cells were incubated for 16 hours prior to determination of cell viability. In experiments to assess the neuroprotection by KP, CRH, or catalase the KP 1-54 $(10 \mu \mathrm{M})$, $\mathrm{CRH}(10 \mathrm{nM})$, or catalase $(5 \mu \mathrm{g} / \mathrm{mL})$ was incubated for $4 \mathrm{~h}$ with the $\mathrm{A} \beta 1-42(10 \mu \mathrm{M})$ to allow binding to occur prior to addition to cells. The mixtures of $\mathrm{A} \beta 1-42$ plus either media alone or KP 1-54, CRH, or catalase were added to cells to induce toxicity and incubated for 16 hours prior to determination of cell viability.

2.9. Cell Viability. After treatment with test peptides or drugs and incubation for the appropriate time, the viability was determined by MTT reduction [21]. After incubation with test substances, MTT (10 $\mu \mathrm{L}: 12 \mathrm{mM}$ stock) was added and cells incubated for a further 4 hours. Cell lysis buffer (100 $\mu \mathrm{L} /$ well; $20 \%$ (v/v) SDS, 50\% (v/v) N,N-dimethylformamide, $\mathrm{pH}$ 4.7) was added, and after repeated pipetting to lyse cells, the MTT formazan product formation was determined by measurement of absorbance change at $570 \mathrm{~nm}$. Control levels in the absence of test substances were taken as $100 \%$ and the absorbance in the presence of cells lysed with Triton X-100 at the start of the incubation period with test substances taken as $0 \%$ [54].

2.10. Data Analysis. All data are expressed as means \pm SEM for ir-KP measurements levels in samples were determined from a standard curve using synthetic KP $45-54$ as the standard. For cytotoxicity experiments data are expressed as \% control cells (MTT reduction). Statistical analysis was performed by one-way analysis of variance (ANOVA) with Tukey or Dunnett multiple comparison post hoc testing using GraphPad Prism software (version 6), with a $P$ value of $<0.05$ considered statistically significant.

\section{Results}

3.1. Characterization of Antibodies. The binding of BAM-10 mouse anti- $A \beta$ antibody [44], rabbit anti- $A \beta 21-32$ antiserum [45], rabbit anti-KP 45-54 antiserum [17], CAT-505 mouse anti-catalase antibody [49], and КСНMB001 mouse antiCRH antibody [46] to A $\beta$, KP, NPFF, catalase, and CRH was tested. Both of anti-A $\beta$ antibodies, BAM- 10 mouse anti-A $\beta$ and rabbit anti-A $\beta 21-32$, showed significant binding to full length $A \beta$ but not to KP, NPFF, catalase, or CRH (Figure 1(a)). The BAM-10 antibody did not bind $\mathrm{A} \beta$ 17-40 in agreement with the published specificity of this antibody for $A \beta 1-12[44$, $55,56]$, whilst the anti-A $\beta 21-32$ antibody showed significant binding to A $\beta$ 17-40. The anti-KP 45-54 antibody showed significant binding to KP 1-54 plus KP 45-54 and also showed significant binding to NPFF but did not cross-react with $\mathrm{A} \beta$, catalase, or CRH (Figure 1(a)). The CAT-505 anti-catalase antibody showed significant binding to catalase and showed no cross-reactivity with $\mathrm{A} \beta, \mathrm{KP}, \mathrm{NPFF}$, or CRH peptides. The KCHMB001 anti-CRH antibody showed significant binding to $\mathrm{CRH}$ and showed no cross-reactivity with $\mathrm{A} \beta, \mathrm{KP}, \mathrm{NPFF}$ or catalase.

The BAM-10 anti-A $\beta$, anti-A $\beta$ 21-32, and anti-KP 45-54 antibodies all showed significant binding to plates coated with A $\beta$ 1-42 fibrils and pretreated with KP 45-54 (Figure 1(b)). The BAM-10 anti-A $\beta$ and anti-A $\beta 21-32$ antibodies but not the anti-KP 45-54 antibody showed significant binding to plates coated with $A \beta 1-42$ fibrils and pretreated with NPFF (Figure 1(b)). This observation contrasts with the cross-reactivity of the anti-KP 45-54 antibody with NPFF (Figure 1(a)) and suggests either that no specific binding of NPFF to $\mathrm{A} \beta$ had occurred or that the epitope of NPFF recognized by the antibody is inaccessible for antibody binding when the NPFF is bound to $\mathrm{A} \beta$. The CAT-505 anti-catalase antibody showed no significant binding to plates coated with $A \beta 1-42$ fibrils and pretreated with either KP 45-54 or NPFF (Figure 1(b)). The BAM-10 anti-A $\beta$, anti-A $\beta$ 21-32, and CAT-505 anti-catalase antibodies showed significant binding to plates coated with $A \beta 1-42$ fibrils and pretreated with catalase (Figure 1(b)). The anti-KP 45-54 antibody showed no binding to plates coated with $\mathrm{A} \beta$ 1-42 fibrils and pretreated with catalase (Figure 1(b)). The KCHMB001 anti-CRH antibody showed no significant binding to plates coated with $\mathrm{A} \beta$ 1-42 fibrils or those pretreated with either CRH, KP 45-54, NPFF, or catalase (Figure 1(b)), suggesting that either no specific $\mathrm{CRH}$ binding to $\mathrm{A} \beta$ had occurred or that the epitope of CRH recognized by the antibody is inaccessible for antibody binding when the $\mathrm{CRH}$ is bound to $\mathrm{A} \beta$. The $\mathrm{BAM}-10$ anti-A $\beta$ and anti-A $\beta$ 21-32 antibodies showed significant binding tolinebreak plates coated with $A \beta 1-42$ fibrils and pretreated with CRH (Figure 1(b)).

3.2. Double-Labeling Immunohistochemistry for $K P$ and $A \beta$ in a Normal Control. Immunohistochemistry analysis with anti-KP 45-54 alone in pons sections from a 26-year-old normal male (Cat. no. ab4316; Lot no. A504234) showed staining that was detectable with green fluorescence but not red fluorescence. Immunohistochemistry analysis with $\mathrm{BAM}-10$ anti-A $\beta$ alone showed staining that was detectable 


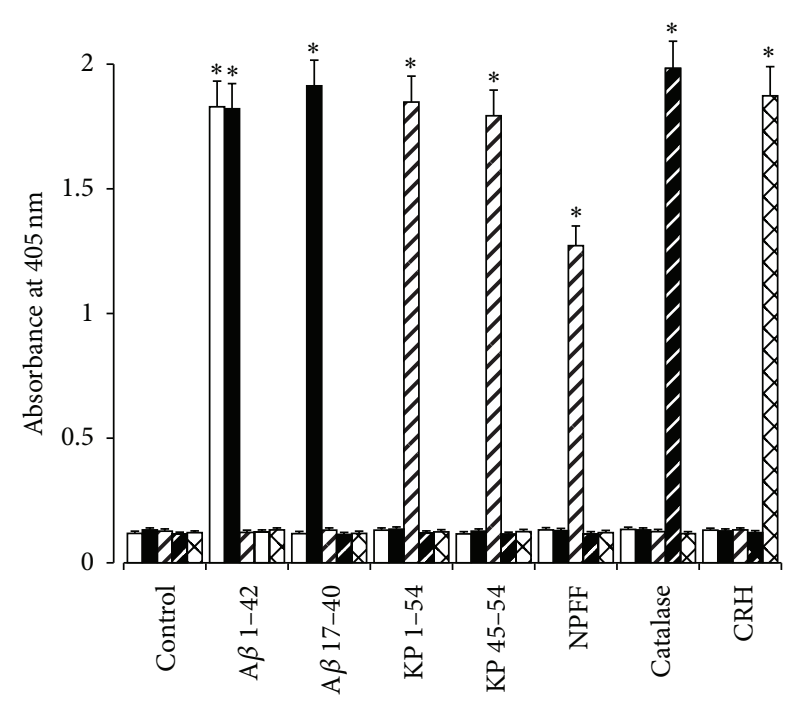

(a)

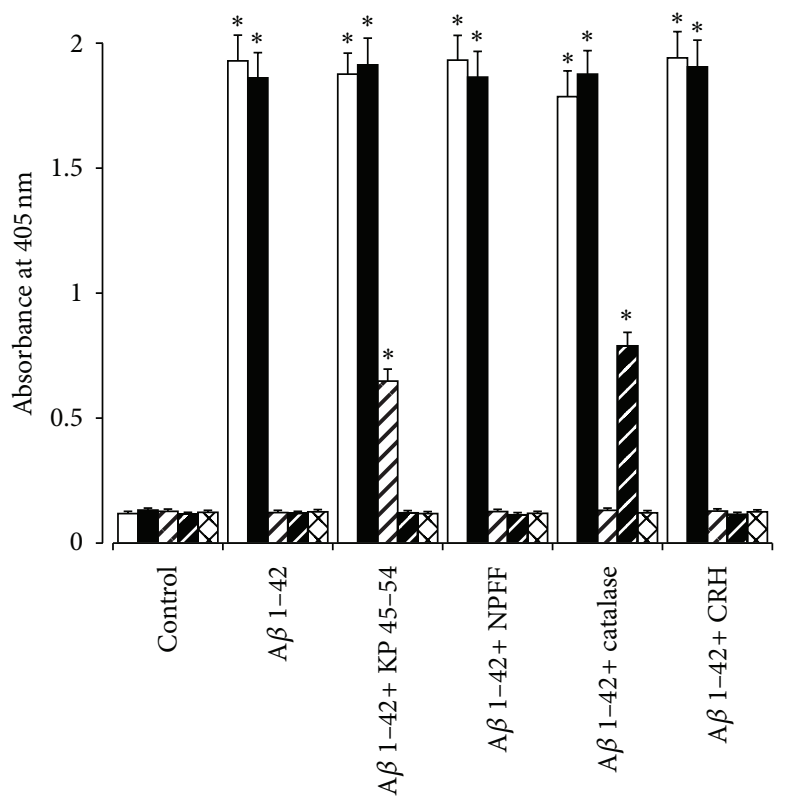

(b)

FIGURE 1: Binding of anti-A $\beta$, anti-KP, anti-catalase and anti-CRH antibodies to $\mathrm{A} \beta, \mathrm{KP}, \mathrm{NPFF}$, catalase and CRH. In (a) plates were coated with A $\beta$ 1-42, A $\beta$ 17-40, KP 1-54, KP 45-54, NPFF, catalase, and CRH. Binding of BAM-10 mouse anti-A $\beta$ antibody (open columns), rabbit anti-A $\beta$ 21-32 antiserum (closed columns), rabbit anti-KP 45-54 antiserum (open hatched columns), CAT-505 mouse anti-catalase antibody (closed hatched columns) and KCHMB001 mouse anti-CRH antibody (open cross-hatched columns) was detected using alkaline phosphatase conjugated secondary antibodies and p-nitrophenylphosphate substrate. In (b) plates coated with A $\beta 1-42$ fibrils were preincubated with KP 45-54, NPFF, catalase, or CRH before addition of BAM-10 mouse anti-A $\beta$ antibody (open columns), rabbit anti-A $\beta$ 21-32 antiserum (closed columns), rabbit anti-KP 45-54 antiserum (open hatched columns) and CAT-505 mouse anti-catalase antibody (closed hatched columns), KCHMB001 mouse anti-CRH antibody (open cross-hatched columns). Binding was detected using alkaline phosphatase conjugated secondary antibodies and p-nitrophenylphosphate substrate. Results are expressed as mean \pm SEM $(n=8)$ absorbance change at $405 \mathrm{~nm} .\left({ }^{*}=P<0.05\right.$ versus control; one-way ANOVA).

with red fluorescence but not green fluorescence. Control incubations with secondary antibodies showed no detectable staining above background. The results from the doublelabeling immunohistochemistry showed staining of tissue with the anti-KP 45-54 (Figure 2(a)) and BAM-10 anti-A $\beta$ (Figure 2(b)) antibodies. There was no colocalization of antiKP 45-54 and BAM-10 anti-A $\beta$ labeling observed in the tissue (Figure 2(c)).

3.3. Double-Labeling Immunohistochemistry for $K P$ and $A \beta$ in $A D$. The results from the double-labeling immunohistochemistry in the pons sections from a 72-year-old male with $\mathrm{AD}$ (Cat. no. ab4586; Lot no. B506287) show that the antiKP 45-54 (Figure 3(a)) and BAM-10 anti-A $\beta$ (Figure 3(b)) antibodies labeled deposits. The anti-KP $45-54$ staining was shown to colocalize with the BAM-10 anti-A $\beta$ labeling in the plaque-like deposits (Figure 3(c)). The KP labeling was unaltered by preincubation of the antibody with NPFF [51] (Figures 3(d), 3(e), and 3(f)), and colocalization with the BAM-10 anti-A $\beta$ labeling was still observed. The colocalization of KP and $\mathrm{A} \beta$ appeared to be confined to plaque-like deposits rather than throughout the tissue (Figures 3(c) and 3(f)). Control incubations with secondary antibodies showed no detectable staining or colocalization in plaque-like deposits above the background for green fluorescence (Figures 3(g) and 3(i)) or red fluorescence (Figures 3(h) and 3(i)).
3.4. Double-Labeling Immunohistochemistry for $\mathrm{CRH}$ and $A \beta$. To confirm the observations of Powers et al. (1987) [34] that $\mathrm{CRH}$ is present in $\mathrm{AD}$ amyloid plaques double labeling immunohistochemistry with a polyclonal anti-A $\beta 21-32$ antibody and the KCHMB001 monoclonal anti-CRH antibody was carried out. The results showed labeling with both antibodies and colocalization of the $\mathrm{A} \beta$ and $\mathrm{CRH}$ in plaque-like deposits (Figures 4(a), 4(b) and 4(c)). The $\mathrm{A} \beta$ labeling with the anti-A $\beta$ 21-32 polyclonal primary antibody (Figure 4(b)) showed a similar pattern of $A \beta$ labeling to that seen with the BAM-10 monoclonal anti-A $\beta$ antibody (Figure 3(b)).

\subsection{Double-Labeling Immunohistochemistry for Catalase and} $A \beta$. To confirm the observations of Pappolla et al. (1992) [23] that catalase is present in $\mathrm{AD}$ amyloid plaques doublelabeling immunohistochemistry with a polyclonal anti-A $\beta$ 21-32 antibody and the CAT-505 monoclonal anti-catalase antibody was carried out. The results showed labeling with both antibodies and colocalization of the $\mathrm{A} \beta$ and catalase in plaque like deposits (Figures 5(a), 5(b), and 5(c)).

3.6. Double-Labeling Immunohistochemistry for KP and Catalase. The lack of $\mathrm{A} \beta$ positive deposits that did not show KP or catalase labeling suggested that the two compounds might colocalize in the plaques. Double-labeling immunohistochemistry results showed that this was the case 


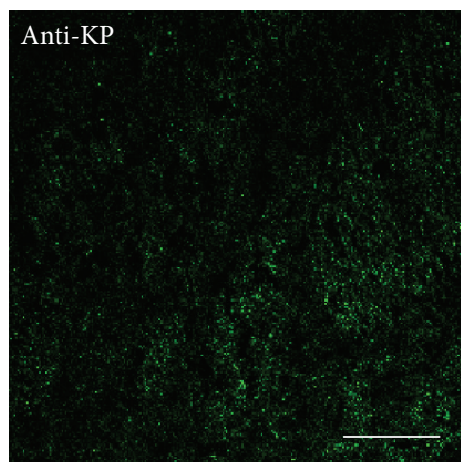

(a)

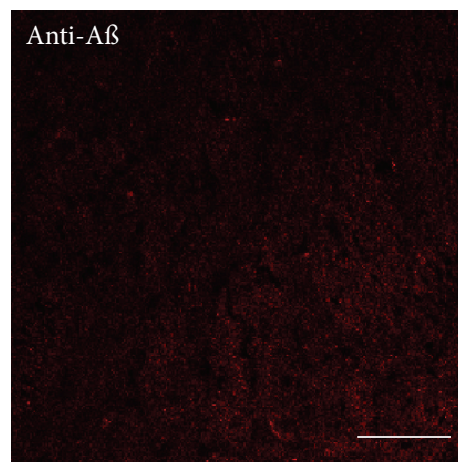

(b)

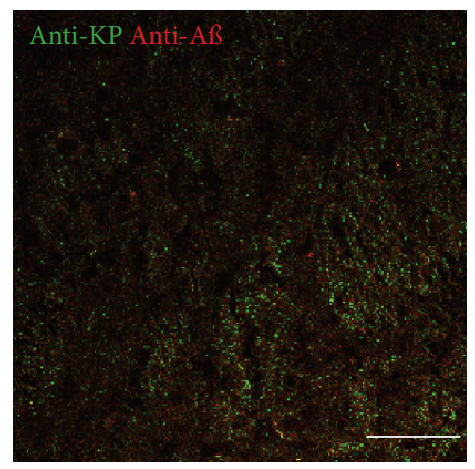

(c)

FIGURE 2: Double-labeling immunofluorescence demonstrating colocalization of kisspeptin (KP) and amyloid- $\beta(\mathrm{A} \beta)$ in the pons of a normal control $(\mathrm{a}-\mathrm{c})$. KP appears green, and $\mathrm{A} \beta$ appears red. The overlap of $\mathrm{KP}$ and $\mathrm{A} \beta$ appears yellow. Bars $=50 \mu \mathrm{m}$.

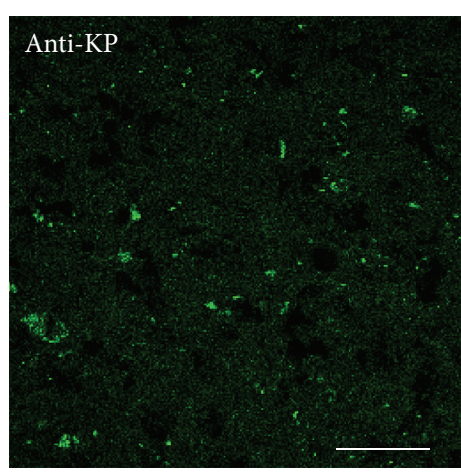

(a)

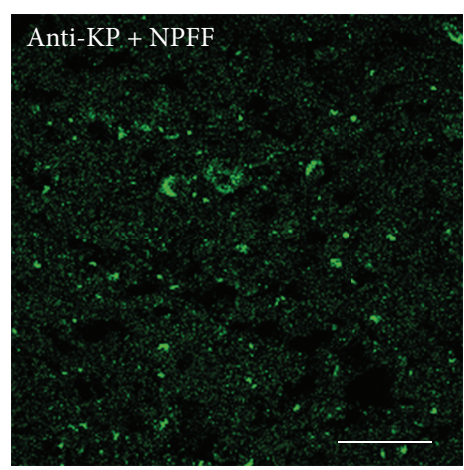

(d)

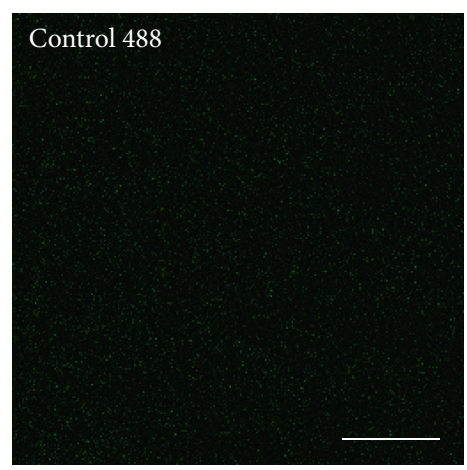

$(\mathrm{g})$

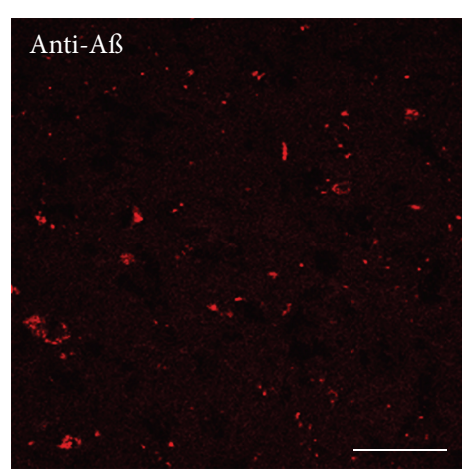

(b)

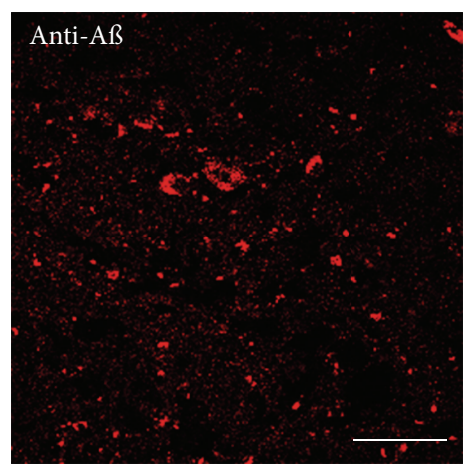

(e)

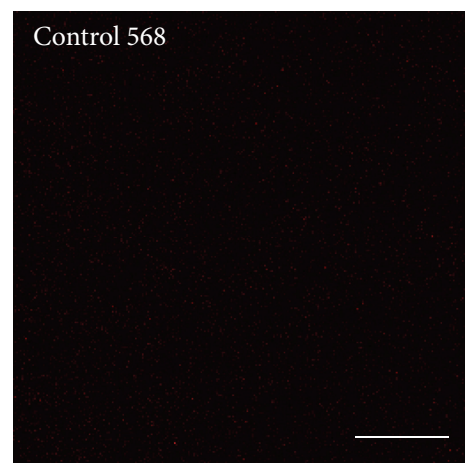

(h)

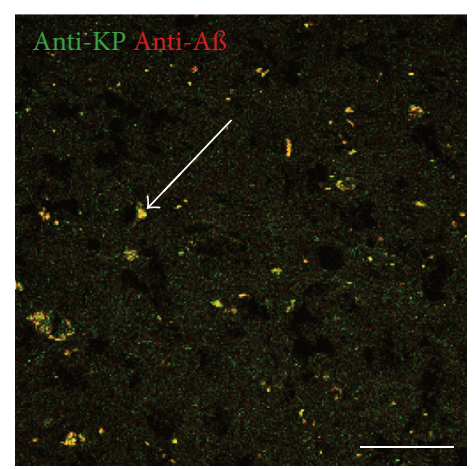

(c)

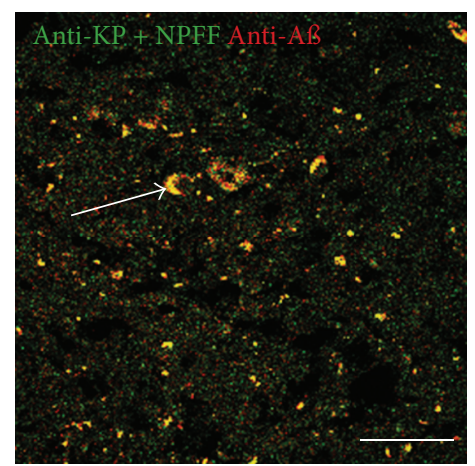

(f)

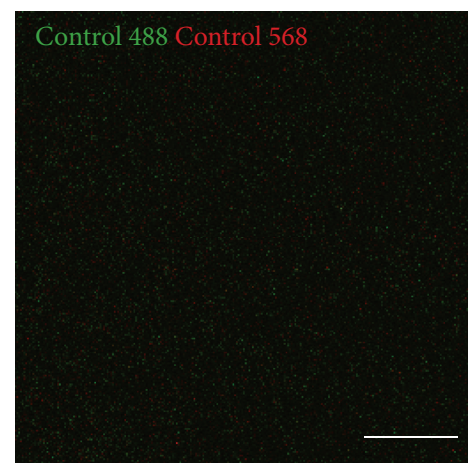

(i)

FIGURE 3: Double-labeling immunofluorescence demonstrating colocalization of kisspeptin (KP) and amyloid- $\beta$ (A $\beta$ ) in the pons in Alzheimer's disease (a-f). Staining due to nonspecific binding of secondary antibodies is shown in (g-i). KP appears green, and A $\beta$ appears red. The overlap of KP and A $\beta$ appears yellow, and examples are labeled with arrows in (c) and (f). Bars $=50 \mu \mathrm{m}$. 


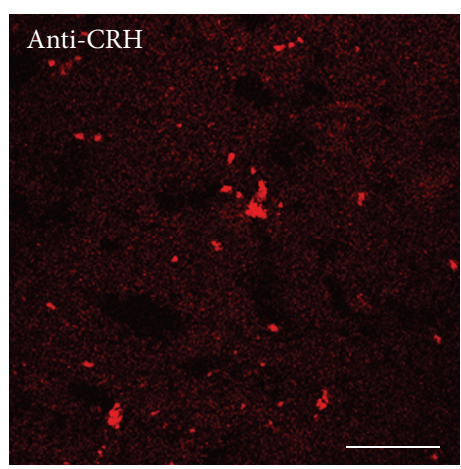

(a)

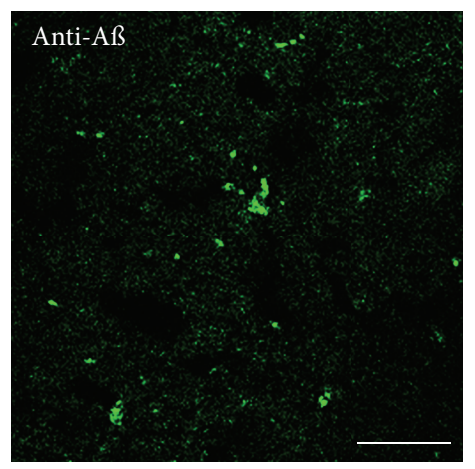

(b)

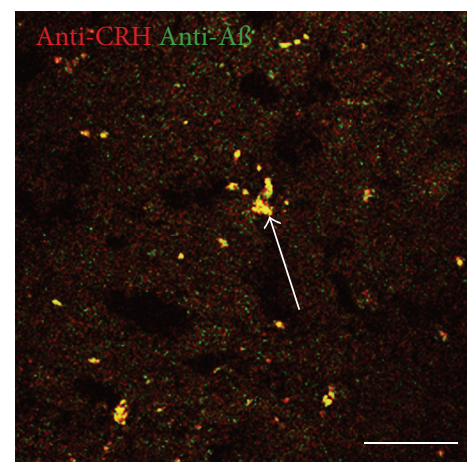

(c)

FIGURE 4: Double-labeling immunofluorescence demonstrating colocalization of CRH and A $\beta$ in the pons in Alzheimer's disease (a-c). CRH appears red, and $\mathrm{A} \beta$ appears green. The overlap of $\mathrm{CRH}$ and $\mathrm{A} \beta$ appears yellow, and an example is labeled with an arrow in (c). Bars $=50 \mu \mathrm{m}$.

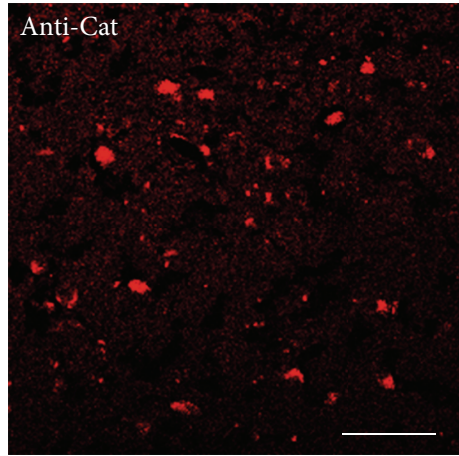

(a)

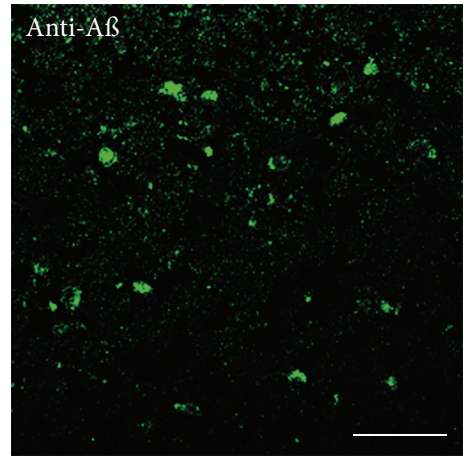

(b)

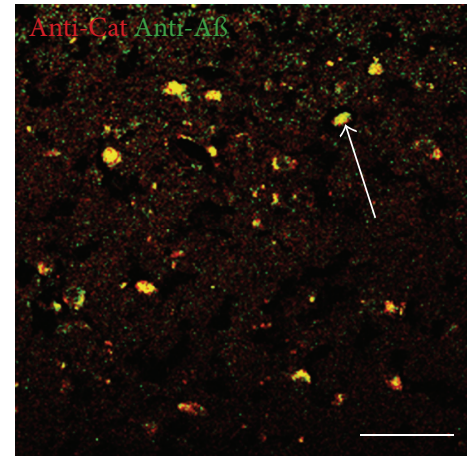

(c)

FIGURE 5: Double-labeling immunofluorescence demonstrating colocalization of catalase and $\mathrm{A} \beta$ in the pons in Alzheimer's disease (a-c). Catalase appears red, and $\mathrm{A} \beta$ appears green. The overlap of catalase and $\mathrm{A} \beta$ appears yellow, and an example is labeled with an arrow in (c). Bars $=50 \mu \mathrm{m}$.

(Figures 6(a), 6(b), and 6(c)). Of interest was the observation at higher magnification that there appeared to be specific $\mathrm{KP}$ and catalase sites with only limited colocalization within plaque-like deposits (Figures 6(d), 6(e), and 6(f)).

3.7. Fibrillar A $\beta$ Stimulation of KP Release. The effects of fibrillar $\mathrm{A} \beta$ peptides on endogenous KP release were tested using human SH-SY5Y neurons. The assay used cross-reacts with KP 1-54, KP 27-54, KP 42-54, KP 45-54, and KP 4550 but not KP 47-50 or NPFF. Results showed that fibrillar $\mathrm{A} \beta$ 1-46, $\mathrm{A} \beta$ 1-43, $\mathrm{A} \beta$ 1-42, $\mathrm{A} \beta$ 1-40, $\mathrm{A} \beta$ 1-38, $\mathrm{A} \beta$ 17-40, and $A \beta 25-35$ all stimulated a significant 3-4-fold increase, from a basal level of $10.5 \pm 0.6 \mathrm{pg} / \mathrm{mL}$, in ir-KP release from SH-SY5Y neurons during a 4-hour incubation (Figure 7(a)). A dose response curve for fibrillar A $\beta$ 1-42 stimulated ir$\mathrm{KP}$ release showed that at doses above $100 \mathrm{nM}$ there was a significant increase in ir-KP release (Figure 7(b)). At the two highest doses $(1 \mu \mathrm{M}$ and $10 \mu \mathrm{M})$ there was significant ir-KP release; however, this was accompanied by neurotoxicity, and it is likely that the higher levels may be due to KP released from dead cells rather than KP directly stimulated by $\mathrm{A} \beta$.
3.8. Effect of KP, CRH, and Catalase on Fibrillar A $\beta 1-42$ Toxicity. In order to inhibit endogenous $\mathrm{KP}, \mathrm{CRH}$, and catalase the effects of the anti-KP 45-54 antibody, the KCHMB001 anti$\mathrm{CRH}$ antibody, and the catalase inhibitor $3 \mathrm{AT}$ on fibrillar $\mathrm{A} \beta$ 1-42 toxicity were tested using human SH-SY5Y neurons. The results showed that both the anti-KP 45-54 antibody and the catalase inhibitor 3AT caused a significant enhancement of A $\beta$ 1-42 toxicity (Figure 8(a)), whilst the KCHMB001 anti$\mathrm{CRH}$ antibody had no effect.

The direct effects of the KP 1-54, CRH, and catalase on fibrillar A $\beta$ 1-42 toxicity were also tested using human SH-SY5Y neurons. The results showed that the KP 1-54, $\mathrm{CRH}$, and catalase were all able to prevent $\mathrm{A} \beta$ neurotoxicity (Figure 8(b)).

\section{Discussion}

The colocalization of $\mathrm{KP}$ with $\mathrm{A} \beta$ in plaque-like deposits (Figure 3) is a novel observation. The colocalization of $\mathrm{CRH}$ with $\mathrm{A} \beta$ confirms the observations of Powers et al. (1987) [34] and the colocalization of catalase with $\mathrm{A} \beta$ confirms the 


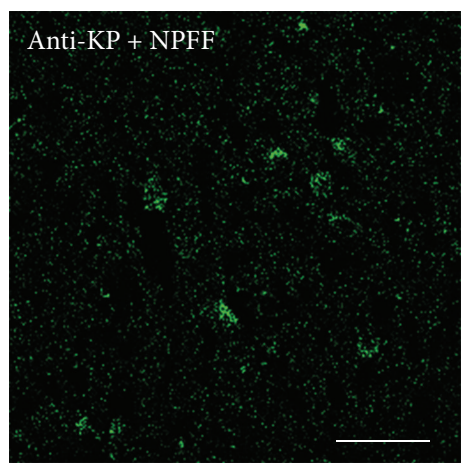

(a)

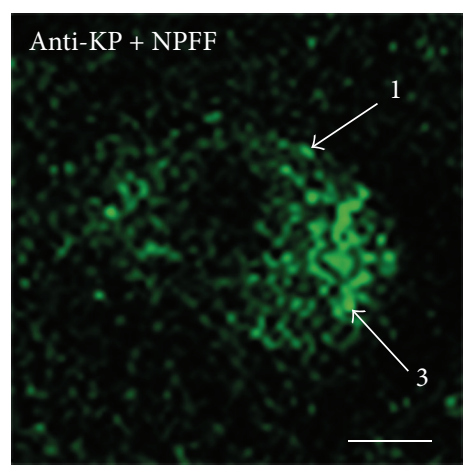

(d)

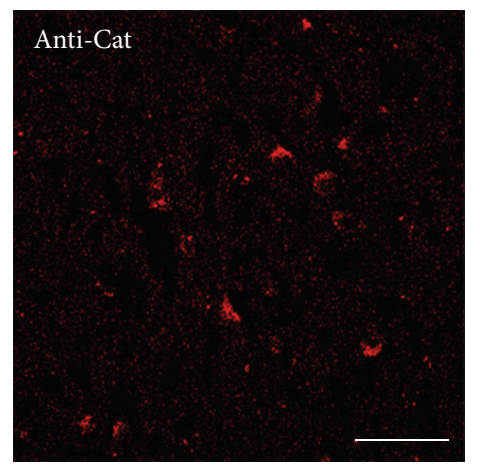

(b)

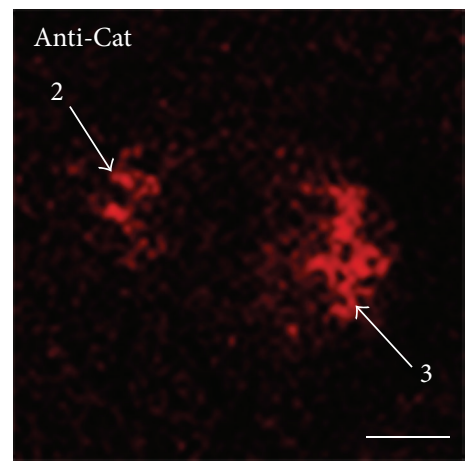

(e)

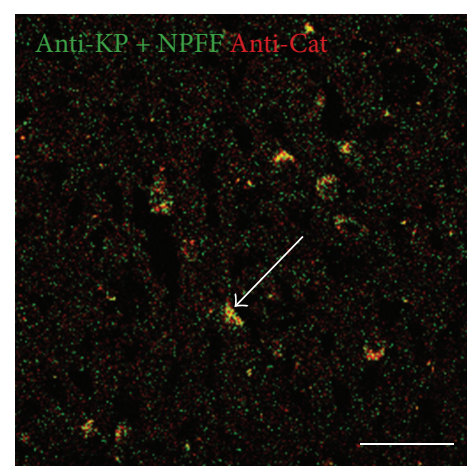

(c)

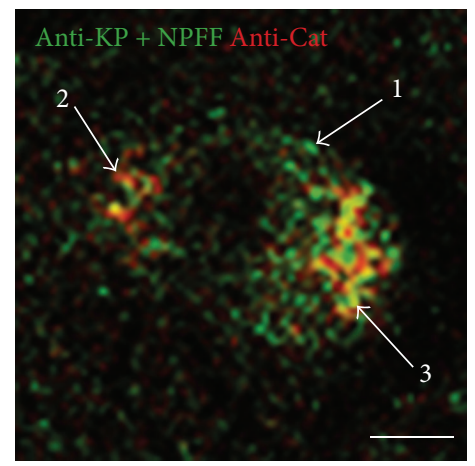

(f)

FIGURE 6: Double-labeling immunofluorescence demonstrating colocalization of KP and catalase in the pons in Alzheimer's disease (a-f). $\mathrm{KP}$ appears green, and catalase appears red. The overlap of KP and catalase appears yellow (merge), and an example is labeled with an arrow in (c). The arrows labeled 1 correspond to an example of KP only labeled in (d) and (f); arrows labeled 2 correspond to an example of catalase only label in (e) and (f); and arrows labeled 3 correspond to an example of KP and catalase colocalizing in (d), (e), and (f). Bars = 50 $\mu \mathrm{m}$ (a) $-(\mathrm{c})$ and $5 \mu \mathrm{m}(\mathrm{d})-(\mathrm{f})$.

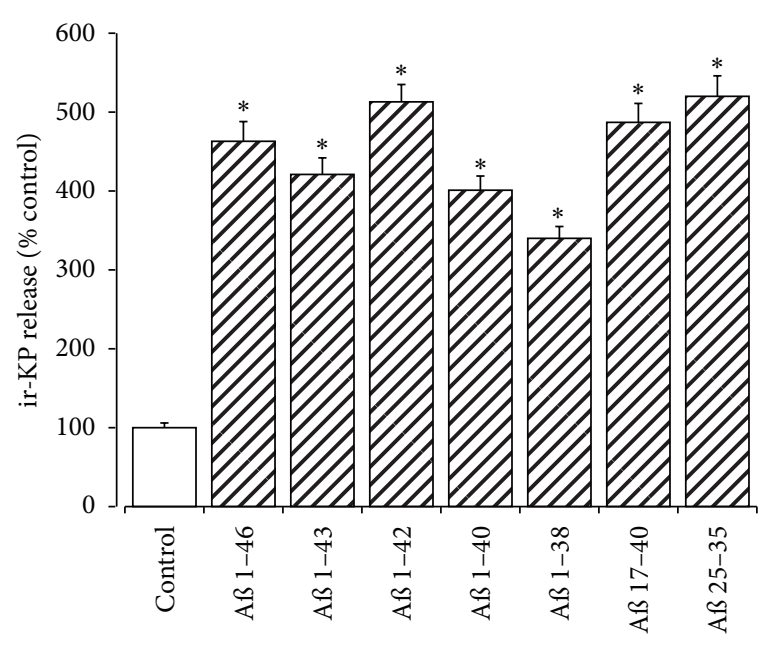

(a)

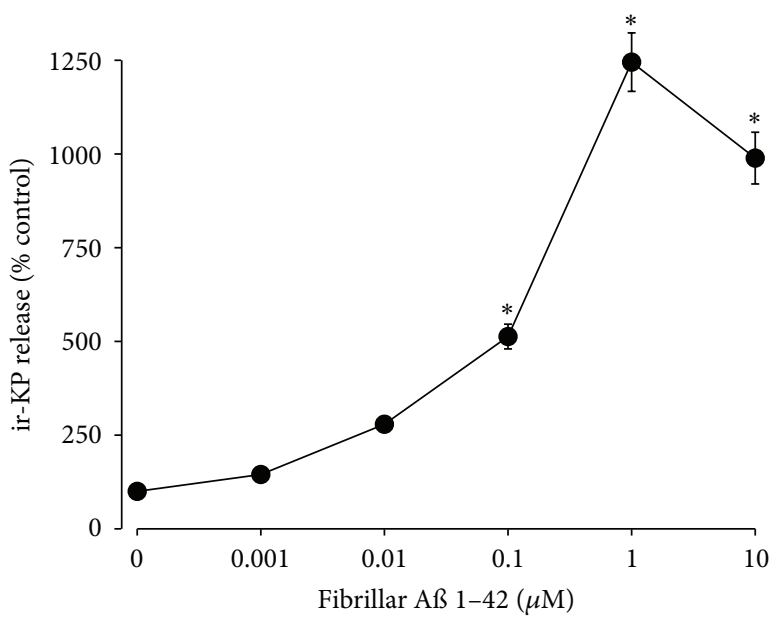

(b)

FIgURE 7: Effects of fibrillar A $\beta$ peptides on ir-KP release from SH-SY5Y neurons. (a) Neuronal SH-SY5Y cell cultures were exposed to fibrillar $\mathrm{A} \beta$ 1-43, $\mathrm{A} \beta 1-42, \mathrm{~A} \beta$ 1-40, $\mathrm{A} \beta$ 1-38, $\mathrm{A} \beta$ 17-40, and $\mathrm{A} \beta 25-35$ peptides (100 nM each) for $4 \mathrm{~h}$. (b) Dose dependent release of ir-KP was determined by incubating SH-SY5Y cell cultures with fibrillar A $\beta$ 1-42 $(0-10 \mu \mathrm{M})$ for $4 \mathrm{~h}$. The release of ir-KP into the cell culture media was determined by EIA. All results, as \% control (media alone), are shown as the mean \pm SEM $(n=8)\left({ }^{*}: P<0.05\right.$ versus control (media alone); one-way ANOVA). 


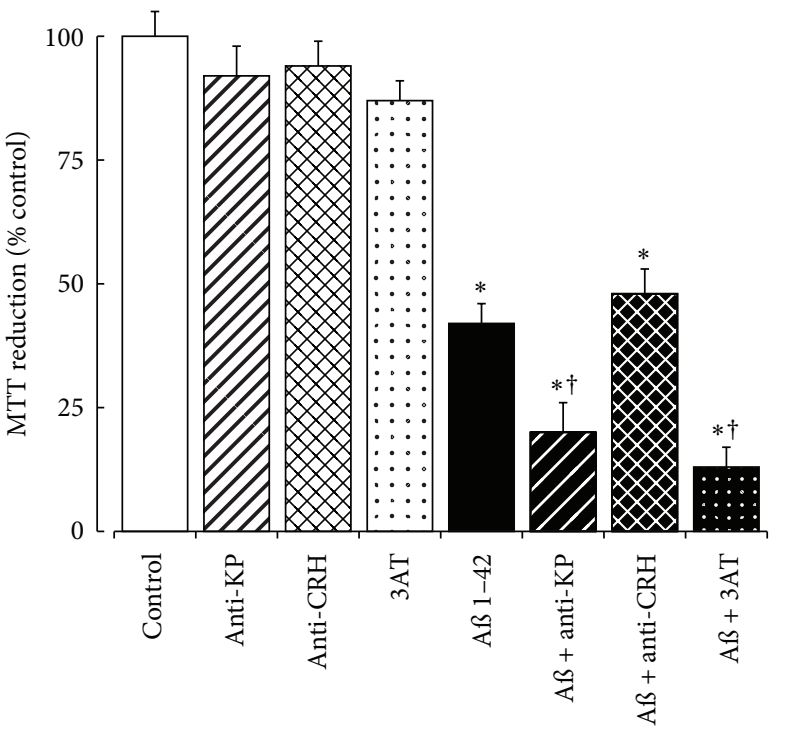

(a)

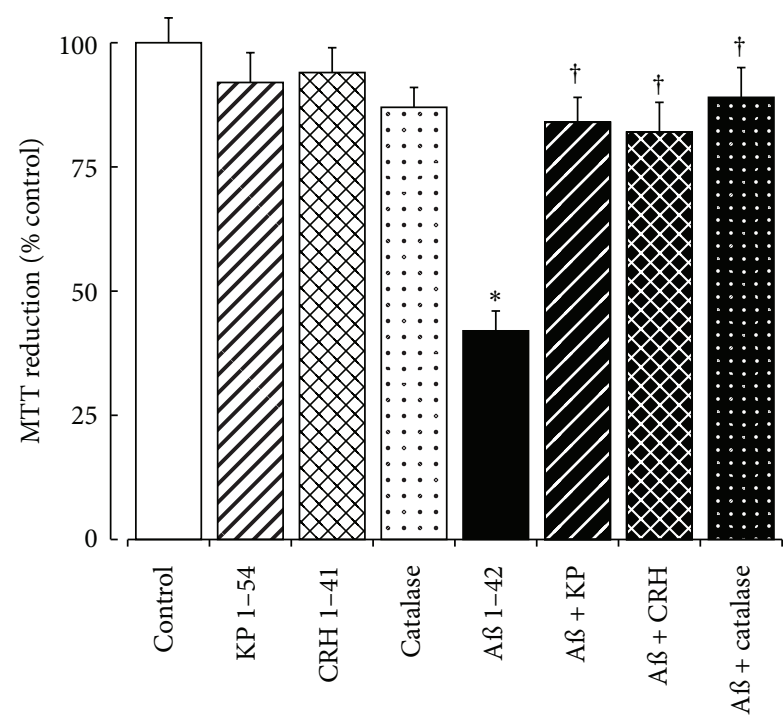

(b)

FIGURE 8: Effects of KP, CRH, and catalase on A $\beta$ toxicity in SH-SY5Y neurons. (a) Neuronal SH-SY5Y cell cultures were exposed to $10 \mu \mathrm{g} / \mathrm{mL}$ anti-KP 45-54 antibody (hatched columns), $10 \mu \mathrm{g} / \mathrm{mL}$ anti-CRH antibody (cross-hatched columns), or $50 \mu \mathrm{M} 3 \mathrm{AT}$ (stippled columns) for 4 hours prior to addition of media (open columns) or fibrillar A $\beta$ 1-42 (10 $\mu \mathrm{M}$ : closed columns). (b) Neuronal SH-SY5Y cell cultures were exposed to $10 \mu \mathrm{M} \mathrm{KP} \mathrm{1-54} \mathrm{(hatched} \mathrm{columns),} 10 \mathrm{nM} \mathrm{CRH} \mathrm{(crosshatched} \mathrm{columns),} \mathrm{or} 5 \mu \mathrm{g} / \mathrm{mL}$ catalase (stippled columns) plus media alone (open columns) or fibrillar A $\beta$ 1-42 (10 $\mu \mathrm{M}$ : closed columns). After incubation for 16 hours, cell viability was determined by the MTT assay. All results are expressed as a \% control (SH-SY5Y cells in media alone) and are expressed as the mean \pm SEM $(n=8)\left({ }^{*}: P<0.05\right.$ versus control (media alone); †: $P<0.05$ versus amyloid fibrils alone; one-way ANOVA).

observations of Pappolla et al. (1992) [23]. The failure of CRH to directly bind $\mathrm{A} \beta$ (Figure $1(\mathrm{~b})$ ) confirms previous studies $[26,31]$ and raises the possibility that the colocalization could be due to either the peptide being trapped within the extracellular debris, that is, part of the amyloid plaques, or that it binds to another component of the plaques. It is not possible from these studies to determine whether the KP in the $\mathrm{A} \beta$ positive deposits has directly bound the $\mathrm{A} \beta$ as described by Milton et al. (2012) [17] or whether it is trapped in the plaque debris. Both KP and catalase bind fibrillar forms of $\mathrm{A} \beta[17,22]$. The lack of secondary antibody binding to the plaque-like deposits suggests that the localization of KP, CRH catalase, and $\mathrm{A} \beta$ observed in these studies is due to direct binding of the primary antibodies to the respective proteins in the deposits. In the case of KP there is a known crossreactivity of KP 45-54 antibodies with NPFF [51]; however, preadsorption of the antibody with NPFF peptide did not reduce the binding, suggesting that the KP is authentic material and not NPFF. Further studies are required to confirm these findings and also determine the regional expression of KP in AD. Changes in hypothalamic KP expression have previously been documented in women at menopause [19], and it is well known that the KiSS-1 expression is regulated by estrogen [57]. The estrogen regulation of KiSS-1 and KP peptides also differs between different brain regions [58$60]$, and it has been suggested that the expression patterns of the $\alpha$ and $\beta$ estrogen receptors are responsible for this [61]. The expressions of the $\alpha$ and $\beta$ estrogen receptors are also changed in $\mathrm{AD}$ [62], and this in turn may alter KiSS1 expression and KP levels. The contribution of the cell surface G-protein-coupled estrogen receptor (GPR30) to KP regulation is unknown, but this form has been found in hippocampal tissue $[63,64]$ and could contribute to changes seen after menopause.

The KP peptides have been shown to be released from human SH-SY5Y neuroblastoma cells in response to fibrillar $\mathrm{A} \beta$ forms (Figure 7) and have previously been shown to be released by other amyloid-fibril forming peptides when in a fibrillar form [17]. The doses of amyloid-fibril forming peptides used previously were subtoxic [17] and selected based on the most toxic fibrillar amyloid peptide; in the current study we also show significant increases in KP release in response to toxic doses. The reduced release at the highest dose of A $\beta$ tested corresponds to a significant toxicity during the incubation time and may be caused by the release of degradative enzymes from dead cells. The levels of KP released are relatively low and suggest that the neuroprotection observed with toxic doses of fibrillar $\mathrm{A} \beta$ is more likely to be receptor mediated rather than via a direct $\mathrm{A} \beta$ binding action. However, in previous studies the KP receptor antagonist or the NPFF receptor antagonist, which blocks some actions of KP [65-67], had no effect on KP neuroprotection [17]. A recent study suggests that the NPFF antagonist RF9 used in previous studies does not block all of the actions of NPFF [68] and these peptides are known to activate acid sensing ion channels (ASICs) in a nonreceptor mediated action [69]. Our observations that KP is present in the pons region of an $\mathrm{AD}$ brain suggest that KP neuroprotection could occur in an $\mathrm{AD}$ setting, and further studies into the mechanism of action of KP may define the mechanism of action. 
The protective roles of catalase are well documented [12, 24-27], and here we confirm enhancement of fibrillar $A \beta$ toxicity by the catalase inhibitor $3 \mathrm{AT}$ plus protection against $\mathrm{A} \beta$ toxicity by catalase (Figure 8 ). The $\mathrm{CRH}$ protection is also well documented $[10,28-33]$ and here is only seen with added $\mathrm{CRH}$ in the SH-SY5Y model. In the pons of AD there are both catalase and $\mathrm{CRH}$ colocalization with $\mathrm{A} \beta$ deposits, suggesting potential neuroprotective roles for catalase or CRH.

\section{Conclusion}

In conclusion, we present evidence of colocalization of KP, $\mathrm{CRH}$, and catalase in $\mathrm{A} \beta$ positive plaque-like deposits in the pons of the $\mathrm{AD}$ brain. The in vitro observations that fibrillar $\mathrm{A} \beta$ stimulates ir-KP release and that both endogenous KP and catalase are neuroprotective suggest potential neuroprotective roles in $\mathrm{AD}$. The colocalization study is the first demonstration of an interaction of $\mathrm{KP}$ with $\mathrm{A} \beta$ in an in vivo $\mathrm{AD}$ setting and suggests a potential role for $\mathrm{KP}$ in $\mathrm{AD}$ pathology.

\section{Conflict of Interests}

Nathaniel G. N. Milton is named as the inventor on patent applications filed by the University of Roehampton for the use of kissorphin peptides to treat Alzheimer's disease, Creutzfeldt-Jakob disease, or diabetes mellitus (Publication nos. GB2493313 A, WO 2011/144714 A1, and EP 2388012 A1); under the University of Roehampton rules he could benefit financially if these patents are granted and commercially exploited.

\section{Authors' Contribution}

Nathaniel G. N. Milton conceived and designed the experiments. Amrutha Chilumuri, Maria Ashioti, Amanda N. Nercessian, and Nathaniel G. N. Milton performed the experiments. Amrutha Chilumuri, Maria Ashioti, Amanda N. Nercessian and Nathaniel G. N. Milton analyzed the data. Nathaniel G. N. Milton wrote the paper. Amrutha Chilumuri, Maria Ashioti, Amanda N. Nercessian and Nathaniel G. N. Milton critically reviewed the paper.

\section{Acknowledgments}

The work was funded by the University of Roehampton plus a Grant from West Focus (Park Board, PCF II 104 to Nathaniel G. N. Milton). The authors would like to thank Drs Anatoliy Markiv and Diluka Peris for assistance with confocal image acquisition.

\section{References}

[1] C. Reitz, "Alzheimer's disease and the amyloid cascade hypothesis: a critical review, International Journal of Alzheimer's Disease, vol. 2012, Article ID 369808, 11 pages, 2012.

[2] E. Karran, M. Mercken, and B. D. Strooper, "The amyloid cascade hypothesis for Alzheimer's disease: an appraisal for the development of therapeutics," Nature Reviews Drug Discovery, vol. 10, no. 9, pp. 698-712, 2011.
[3] D. R. Thal, U. Rüb, M. Orantes, and H. Braak, "Phases of A betadeposition in the human brain and its relevance for the development of AD," Neurology, vol. 58, no. 12, pp. 1791-1800, 2002.

[4] I. Alafuzoff, D. R. Thal, T. Arzberger et al., "Assessment of $\beta$-amyloid deposits in human brain: a study of the BrainNet Europe Consortium," Acta Neuropathologica, vol. 117, no. 3, pp. 309-320, 2009.

[5] B. T. Hyman, C. H. Phelps, T. G. Beach et al., "National Institute on Aging-Alzheimer's Association guidelines for the neuropathologic assessment of Alzheimer's disease," Alzheimer's \& Dementia, vol. 8, no. 1, pp. 1-13, 2012.

[6] T. J. Montine, C. H. Phelps, T. G. Beach et al., "National Institute on Aging-Alzheimer's Association guidelines for the neuropathologic assessment of Alzheimer's disease: a practical approach," Acta Neuropathologica, vol. 123, no. 1, pp. 1-11, 2012.

[7] A. Rijal Upadhaya, E. Capetillo-Zarate, I. Kosterin et al., "Dispersible amyloid $\beta$-protein oligomers, protofibrils, and fibrils represent diffusible but not soluble aggregates: their role in neurodegeneration in amyloid precursor protein (APP) transgenic mice," Neurobiology of Aging, vol. 33, no. 11, pp. 2641-2660, 2012.

[8] D. Caruso, A. M. Barron, M. A. Brown et al., "Age-related changes in neuroactive steroid levels in 3xTg-AD mice," Neurobiology of Aging, vol. 34, no. 4, pp. 1080-1089, 2013.

[9] A. Corrales, P. Martínez, S. García et al., "Long-term oral administration of melatonin improves spatial learning and memory and protects against cholinergic degeneration in middle-aged Ts65Dn mice, a model of Down syndrome," Journal of Pineal Research, vol. 54, no. 3, pp. 346-358, 2013.

[10] Y. Koutmani, P. K. Politis, M. Elkouris et al., "Corticotropinreleasing hormone exerts direct effects on neuronal progenitor cells: implications for neuroprotection," Molecular Psychiatry, vol. 18, no. 3, pp. 300-307, 2013.

[11] G. A. Scullion, K. N. Hewitt, and M. C. Pardon, "Corticotropinreleasing factor receptor 1 activation during exposure to novelty stress protects against alzheimer's disease-like cognitive decline in A $\beta$ PP/PS1 mice," Journal of Alzheimer's Disease, vol. 34, no. 3, pp. 781-793, 2013.

[12] P. Mao, M. Manczak, M. J. Calkins et al., "Mitochondria-targeted catalase reduces abnormal APP processing, amyloid $\beta$ production and BACE1 in a mouse model of Alzheimer's disease: implications for neuroprotection and lifespan extension," Human Molecular Genetics, vol. 21, no. 13, pp. 2973-2990, 2012.

[13] X.-L. Chen, J. Zhang, and C. Chen, "Endocannabinoid 2-arachidonoylglycerol protects neurons against $\beta$-amyloid insults," Neuroscience, vol. 178, pp. 159-168, 2011.

[14] J. Koppel, H. Bradshaw, T. E. Goldberg et al., "Endocannabinoids in Alzheimer's disease and their impact on normative cognitive performance: a case-control and cohort study," Lipids in Health and Disease, vol. 8, article 2, 2009.

[15] V. Micale, C. Mazzola, and F. Drago, "Endocannabinoids and neurodegenerative diseases," Pharmacological Research, vol. 56, no. 5, pp. 382-392, 2007.

[16] A. Dejda, P. Sokołowska, and J. Z. Nowak, "Neuroprotective potential of three neuropeptides PACAP, VIP and PHI," Pharmacological Reports, vol. 57, no. 3, pp. 307-320, 2005.

[17] N. G. N. Milton, A. Chilumuri, E. Rocha-Ferreira, A. N. Nercessian, and M. Ashioti, "Kisspeptin prevention of amyloid- $\beta$ peptide neurotoxicity in vitro," ACS Chemical Neuroscience, vol. 3, no. 9, pp. 706-719, 2012.

[18] E. J. Mead, J. J. Maguire, R. E. Kuc, and A. P. Davenport, "Kisspeptins: a multifunctional peptide system with a role in 
reproduction, cancer and the cardiovascular system," British Journal of Pharmacology, vol. 151, no. 8, pp. 1143-1153, 2007.

[19] N. E. Rance, "Menopause and the human hypothalamus: evidence for the role of kisspeptin/neurokinin B neurons in the regulation of estrogen negative feedback," Peptides, vol. 30, no. 1, pp. 111-122, 2009.

[20] C. Schultz, H. Braak, and E. Braak, "A sex difference in neurodegeneration of the human hypothalamus," Neuroscience Letters, vol. 212, no. 2, pp. 103-106, 1996.

[21] N. G. N. Milton, N. P. Mayor, and J. Rawlinson, "Identification of amyloid- $\beta$ binding sites using an antisense peptide approach," NeuroReport, vol. 12, no. 11, pp. 2561-2566, 2001.

[22] N. G. N. Milton and J. R. Harris, "Polymorphism of amyloid- $\beta$ fibrils and its effects on human erythrocyte catalase binding," Micron, vol. 40, no. 8, pp. 800-810, 2009.

[23] M. A. Pappolla, R. A. Omar, K. S. Kim, and N. K. Robakis, "Immunohistochemical evidence of antioxidant stress in Alzheimer's disease," American Journal of Pathology, vol. 140, no. 3, pp. 621-628, 1992.

[24] N. G. N. Milton, "Inhibition of catalase activity with 3-aminotriazole enhances the cytotoxicity of the Alzheimer's amyloid- $\beta$ peptide," NeuroToxicology, vol. 22, no. 6, pp. 767-774, 2001.

[25] T. Gáspár, F. Domoki, L. Lenti et al., "Neuroprotective effect of adenoviral catalase gene transfer in cortical neuronal cultures," Brain Research, vol. 1270, no. C, pp. 1-9, 2009.

[26] N. G. N. Milton, "Amyloid-beta binds catalase with high affinity and inhibits hydrogen peroxide breakdown," Biochemical Journal, vol. 344, pp. 293-296, 1999.

[27] L. K. Habib, M. T. C. Lee, and J. Yang, "Inhibitors of catalaseamyloid interactions protect cells from beta-amyloid-induced oxidative stress and toxicity," The Journal of Biological Chemistry, vol. 285, no. 50, pp. 38933-38943, 2010.

[28] N. Bayatti and C. Behl, "The neuroprotective actions of corticotropin releasing hormone," Ageing Research Reviews, vol. 4, no. 2, pp. 258-270, 2005.

[29] N. Bayatti, J. Zschocke, and C. Behl, "Brain region-specific neuroprotective action and signaling of corticotropin-releasing hormone in primary neurons," Endocrinology, vol. 144, no. 9, pp. 4051-4060, 2003.

[30] L. Facci, D. A. Stevens, M. Pangallo, D. Franceschini, S. D. Skaper, and P. J. L. M. Strijbos, "Corticotropin-releasing factor (CRF) and related peptides confer neuroprotection via type 1 CRF receptors," Neuropharmacology, vol. 45, no. 5, pp. 623-636, 2003.

[31] N. G. N. Milton, "Anandamide and noladin ether prevent neurotoxicity of the human amyloid- $\beta$ peptide," Neuroscience Letters, vol. 332, no. 2, pp. 127-130, 2002.

[32] W. A. Pedersen, R. Wan, P. Zhang, and M. P. Mattson, "Urocortin, but not urocortin II, protects cultured hippocampal neurons from oxidative and excitotoxic cell death via corticotropinreleasing hormone receptor type I," Journal of Neuroscience, vol. 22, no. 2, pp. 404-412, 2002.

[33] C. R. Elliott-Hunt, J. Kazlauskaite, G. J. C. Wilde, D. K. Grammatopoulos, and E. W. Hillhouse, "Potential signalling pathways underlying corticotrophin-releasing hormone-mediated neuroprotection from excitotoxicity in rat hippocampus," Journal of Neurochemistry, vol. 80, no. 3, pp. 416-425, 2002.

[34] R. E. Powers, L. C. Walker, E. B. DeSouza et al., "Immunohistochemical study of neurons containing corticotropin-releasing factor in Alzheimer's disease," Synapse, vol. 1, no. 5, pp. 405-410, 1987.
[35] D. F. Swaab, A. M. Bao, and P. J. Lucassen, "The stress system in the human brain in depression and neurodegeneration," Ageing Research Reviews, vol. 4, no. 2, pp. 141-194, 2005.

[36] E. B. De Souza, P. J. Whitehouse, D. L. Price, and W. W. Vale, "Abnormalities in corticotropin-releasing hormone (CRH) in Alzheimer's disease and other human disorders," Annals of the New York Academy of Sciences, vol. 512, pp. 237-247, 1987.

[37] G. C. Brailoiu, S. L. Dun, M. Ohsawa et al., "KiSS-1 expression and metastin-like immunoreactivity in the rat brain," Journal of Comparative Neurology, vol. 481, no. 3, pp. 314-329, 2005.

[38] H. R. Kirby, J. J. Maguire, W. H. Colledge, and A. P. Davenport, "International Union of Basic and Clinical Pharmacology. LXXVII. Kisspeptin receptor nomenclature, distribution, and function," Pharmacological Reviews, vol. 62, no. 4, pp. 565-578, 2010.

[39] M. C. Austin, J. E. Janosky, and H. A. Murphy, "Increased corticotropin-releasing hormone immunoreactivity in monoaminecontaining pontine nuclei of depressed suicide men," Molecular Psychiatry, vol. 8, no. 3, pp. 324-332, 2003.

[40] S. Moreno, E. Mugnaini, and M. P. Ceru, "Immunocytochemical localization of catalase in the central nervous system of the rat," Journal of Histochemistry and Cytochemistry, vol. 43, no. 12, pp. 1253-1267, 1995.

[41] J. Samson, R. S. Devi, R. Ravindran, and M. Senthilvelan, "Effect of noise stress on free radical scavenging enzymes in brain," Environmental Toxicology and Pharmacology, vol. 20, no. 1, pp. 142-148, 2005.

[42] N. G. N. Milton and J. R. Harris, "Human islet amyloid polypeptide fibril binding to catalase: a transmission electron microscopy and microplate study," The Scientific World Journal, vol. 10, pp. 879-893, 2010.

[43] N. G. N. Milton and J. R. Harris, "Fibril formation and toxicity of the non-amyloidogenic rat amylin peptide," Micron, vol. 44, pp. 246-253, 2013.

[44] L. A. Kotilinek, B. Bacskai, M. Westerman et al., "Reversible memory loss in a mouse transgenic model of Alzheimer's disease," Journal of Neuroscience, vol. 22, no. 15, pp. 6331-6335, 2002.

[45] N. G. N. Milton, "Phosphorylated amyloid-beta: the toxic intermediate in alzheimer's disease neurodegeneration," Sub-cellular biochemistry, vol. 38, pp. 381-402, 2005.

[46] N. G. N. Milton, E. W. Hillhouse, S. A. Nicholson, C. H. Self, and A. M. McGregor, "Production and utilization of monoclonal antibodies to human/rat corticotrophin-releasing factor-41," Journal of Molecular Endocrinology, vol. 5, no. 2, pp. 159-166, 1990.

[47] N. G. N. Milton, E. W. Hillhouse, and A. S. Milton, "Activation of the hypothalamo-pituitary-adrenocortical axis in the conscious ratbbit by the pyrogen polyinosinic: polycytidylic acid is dependent on corticotrophin-releasing factor-41," Journal of Endocrinology, vol. 135, no. 1, pp. 69-75, 1992.

[48] N. G. N. Milton, E. W. Hillhouse, and A. S. Milton, "A possible role for endogenous peripheral corticotrophin-releasing factor41 in the febrile response of conscious rabbits," Journal of Physiology, vol. 465, pp. 415-425, 1993.

[49] T. S. Hwang, H. K. Choi, and H. S. Han, "Differential expression of manganese superoxide dismutase, copper/zinc superoxide dismutase, and catalase in gastric adenocarcinoma and normal gastric mucosa," European Journal of Surgical Oncology, vol. 33, no. 4, pp. 474-479, 2007.

[50] M. Ashioti, J. S. Beech, A. S. Lowe, M. B. Hesselink, M. Modo, and S. C. R. Williams, "Multi-modal characterisation of the 
neocortical clip model of focal cerebral ischaemia by MRI, behaviour and immunohistochemistry," Brain Research, vol. 1145, no. 1, pp. 177-189, 2007.

[51] N. Iijima, K. Takumi, N. Sawai, and H. Ozawa, "An immunohistochemical study on the expressional dynamics of kisspeptin neurons relevant to $\mathrm{GnRH}$ neurons using a newly developed anti-kisspeptin antibody," Journal of Molecular Neuroscience, vol. 43, no. 2, pp. 146-154, 2011.

[52] A. Markiv, R. Beatson, J. Burchell, R. V. Durvasula, and A. S. Kang, "Expression of recombinant multi-coloured fluorescent antibodies in gor ${ }^{-} / \operatorname{tr} x B^{-}$E. coli cytoplasm," BMC Biotechnology, vol. 11, no. 1, p. 117, 2011.

[53] N. G. N. Milton, "Homocysteine inhibits hydrogen peroxide breakdown by catalase," The Open Enzyme Inhibition Journal, vol. 1, pp. 34-41, 2008.

[54] N. G. N. Milton, "Amyloid- $\beta$ phosphorylation," in Cell Biology Protocols, J. R. Harris, J. M. Graham, and D. Rickwood, Eds., vol. 6, pp. 364-368, John Wiley \& Sons, Chichester, UK, 2006.

[55] A. M. Floden and C. K. Combs, " $\beta$-Amyloid stimulates murine postnatal and adult microglia cultures in a unique manner," Journal of Neuroscience, vol. 26, no. 17, pp. 4644-4648, 2006.

[56] J. F. Jordão, C. A. Ayala-Grosso, K. Markham et al., "Antibodies targeted to the brain with image-guided focused ultrasound reduces amyloid- $\beta$ plaque load in the TgCRND8 mouse model of Alzheimer's disease," PLoS ONE, vol. 5, no. 5, Article ID e10549, 2010.

[57] M. A. Bosch, C. Xue, and O. K. Rønnekleiv, "Kisspeptin expression in guinea pig hypothalamus: effects OF $17 \beta$-Estradiol," Journal of Comparative Neurology, vol. 520, no. 10, pp. 21432162, 2011.

[58] J. Cao and H. B. Patisaul, "Sex-specific expression of estrogen receptors $\alpha$ and $\beta$ and Kiss1 in the postnatal rat amygdala," Journal of Comparative Neurology, vol. 521, no. 2, pp. 465-478, 2013.

[59] J. Kim, S. J. Semaan, D. K. Clifton, R. A. Steiner, S. Dhamija, and A. S. Kauffman, "Regulation of Kiss1 expression by sex steroids in the amygdala of the rat and mouse," Endocrinology, vol. 152, no. 5, pp. 2020-2030, 2011.

[60] D. H. Eghlidi, G. E. Haley, N. C. Noriega, S. G. Kohama, and H. F. Urbanski, "Influence of age and $17 \beta$-estradiol on kisspeptin, neurokinin $\mathrm{B}$, and prodynorphin gene expression in the arcuate-median eminence of female rhesus macaques," Endocrinology, vol. 151, no. 8, pp. 3783-3794, 2010.

[61] J. Cao and H. B. Patisaul, "Sexually dimorphic expression of hypothalamic estrogen receptors $\alpha$ and $\beta$ and Kiss1 in neonatal male and female rats," Journal of Comparative Neurology, vol. 519, no. 15, pp. 2954-2977, 2011.

[62] A. Hestiantoro and D. F. Swaab, "Changes in estrogen receptor$\alpha$ and $-\beta$ in the infundibular nucleus of the human hypothalamus are related to the occurrence of Alzheimer's disease neuropathology," Journal of Clinical Endocrinology and Metabolism, vol. 89, no. 4, pp. 1912-1925, 2004.

[63] T. Funakoshi, A. Yanai, K. Shinoda, M. M. Kawano, and Y. Mizukami, "G protein-coupled receptor 30 is an estrogen receptor in the plasma membrane," Biochemical and Biophysical Research Communications, vol. 346, no. 3, pp. 904-910, 2006.

[64] S. B. Cheng, J. A. Quinn, C. T. Graeber, and E. J. Filardo, "Downmodulation of the G-protein-coupled estrogen receptor, GPER, from the cell surface occurs via a trans-golgi-proteasome pathway," The Journal of Biological Chemistry, vol. 286, no. 25, pp. 22441-22455, 2011.
[65] Y. Lyubimov, M. Engstrom, S. Wurster, J. M. Savola, E. R. Korpi, and P. Panula, "Human kisspeptins activate neuropeptide FF2 receptor," Neuroscience, vol. 170, no. 1, pp. 117-122, 2010.

[66] S. Oishi, R. Misu, K. Tomita et al., "Activation of neuropeptide FF receptors by kisspeptin receptor ligands," ACS Medicinal Chemistry Letters, vol. 2, no. 1, pp. 53-57, 2011.

[67] N. G. N. Milton, "In vitro activities of kissorphin, a novel hexapeptide KiSS-1 derivative, in neuronal cells," Journal of Amino Acids, vol. 2012, Article ID 691463, 6 pages, 2012.

[68] L. Maletínská, A. Tichá, V. Nagelová et al., "Neuropeptide FF analog RF9 is not an antagonist of NPFF receptor and decreases food intake in mice after its central and peripheral administration," Brain Research, vol. 1498, pp. 33-40, 2013.

[69] S. Catarsi, K. Babinski, and P. Séguéla, "Selective modulation of heteromeric ASIC proton-gated channels by neuropeptide FF," Neuropharmacology, vol. 41, no. 5, pp. 592-600, 2001. 


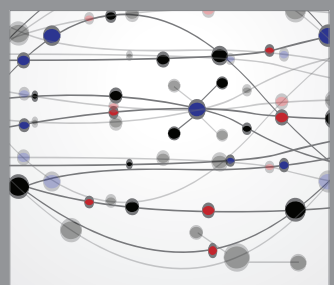

The Scientific World Journal
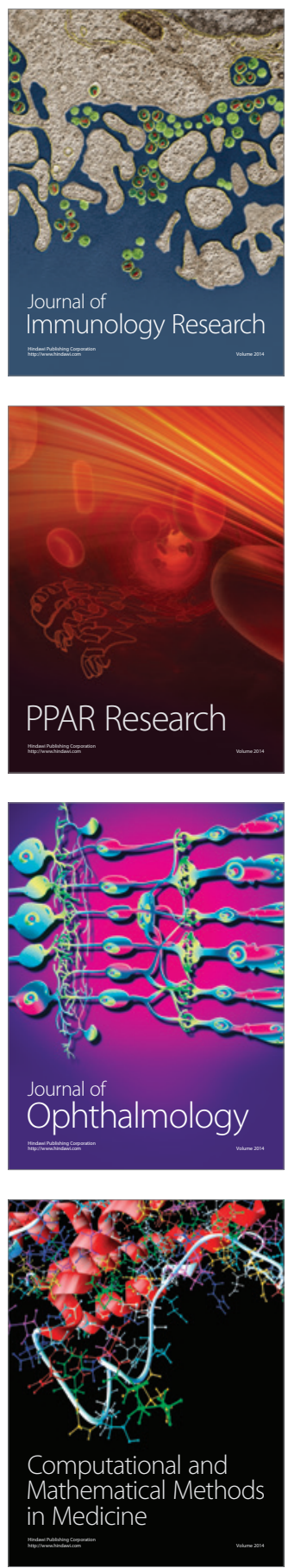

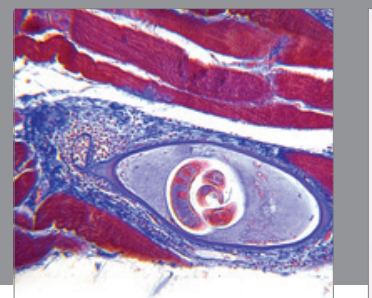

Gastroenterology

Research and Practice
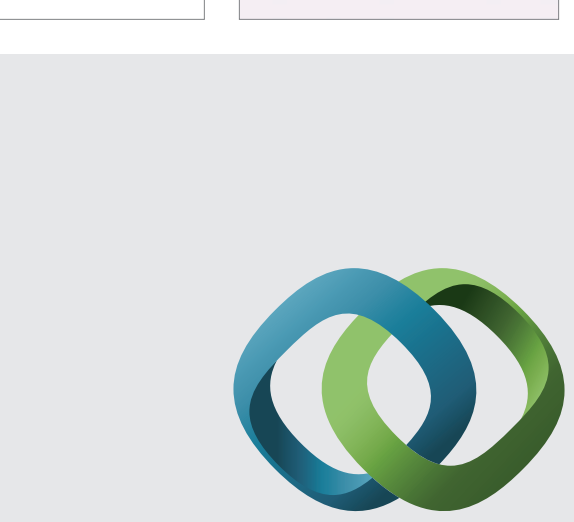

\section{Hindawi}

Submit your manuscripts at

http://www.hindawi.com
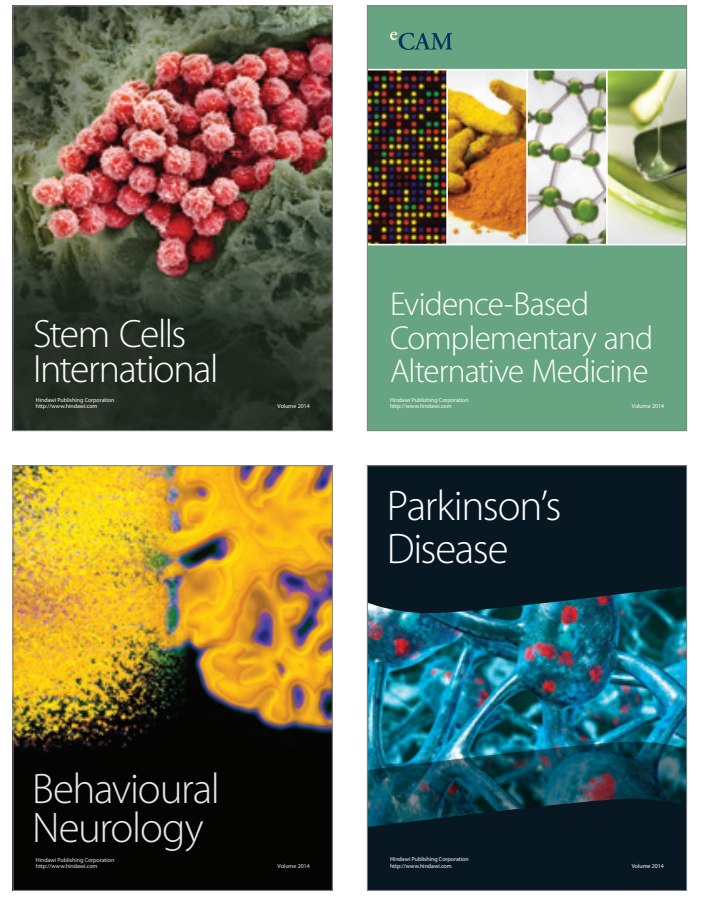
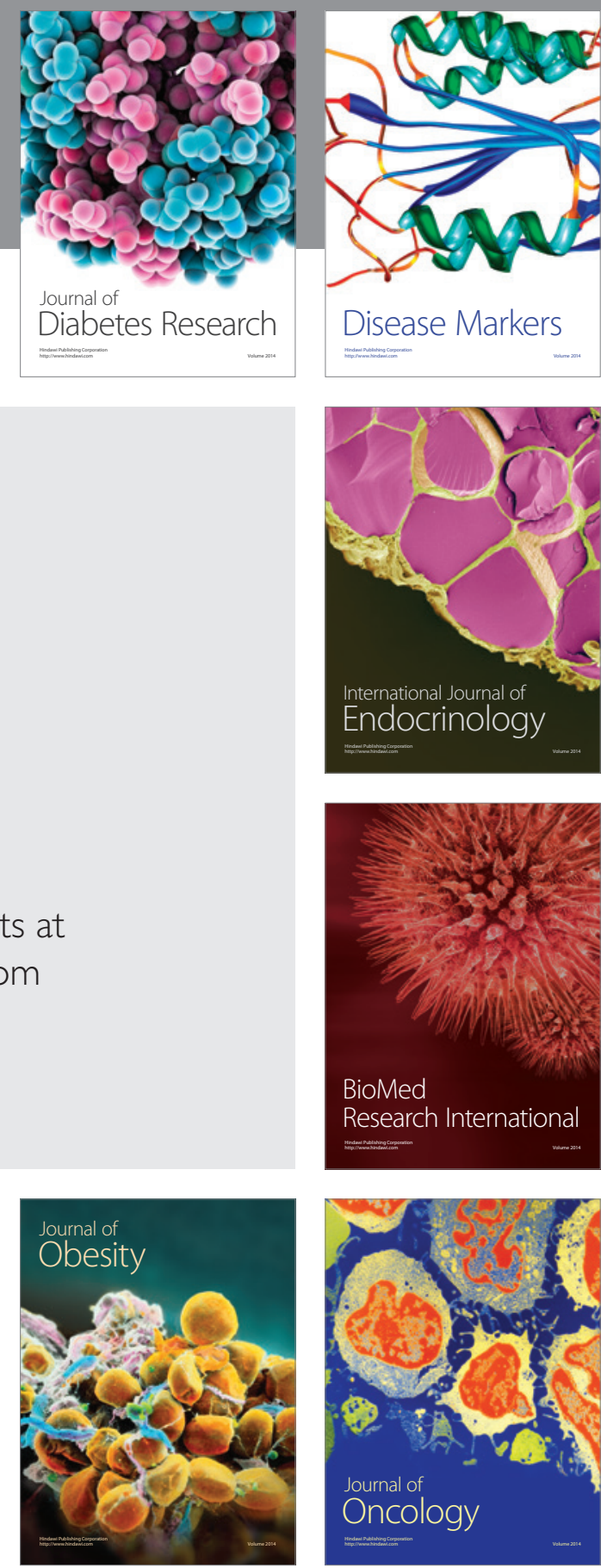

Disease Markers
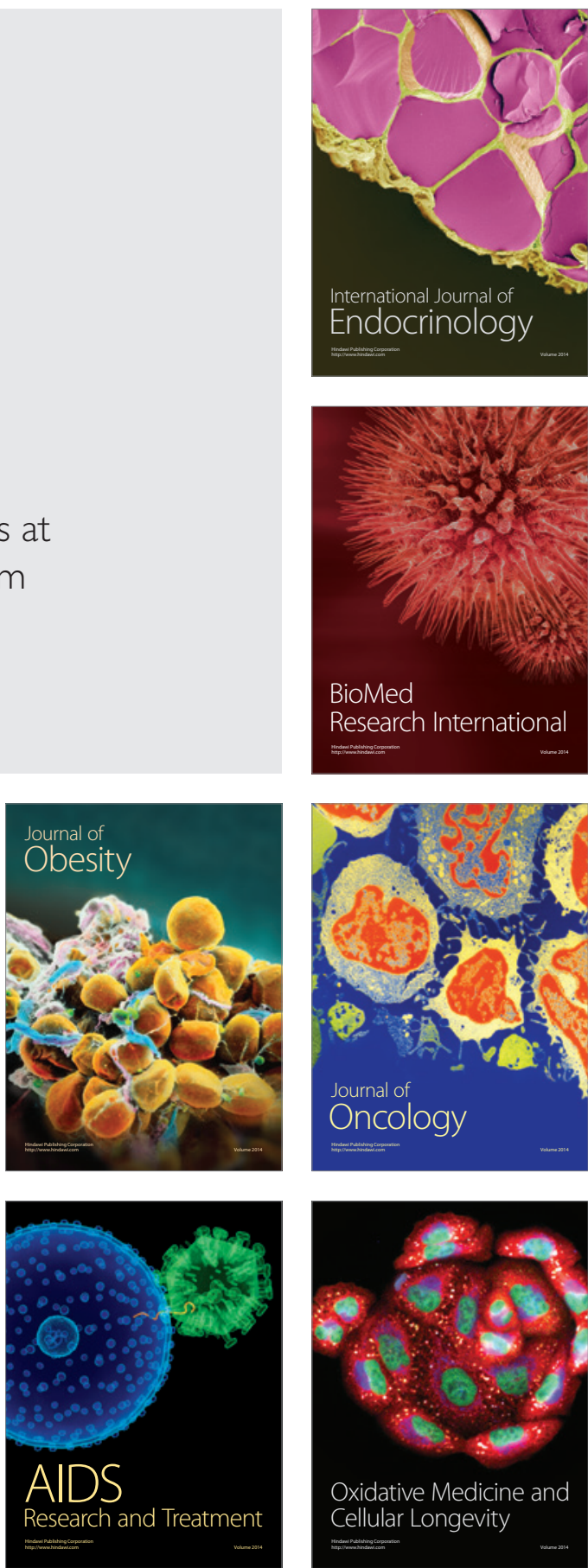